\title{
Some Evidence on the Effect of the \\ Separation of. Spending and Taxing \\ Decisions
}

\author{
by \\ Stanley L. Winer \\ Carleton university \\ ottawa, K1S 5B6
}

October, 1979

I am indebted to Irwin Gillespie, Jim Johnson,

Soo Bin Park, Tom Rymes, Dan Usher and

Ed West for helpful comments on earlier

drafts. Of course, they should be absolved

from any responsibility. 


$\frac{\frac{\text { Some Evidence oh the Effect of the }}{\text { Separation of Spending and Taxing }}}{\underline{\text { Decisions }}}$

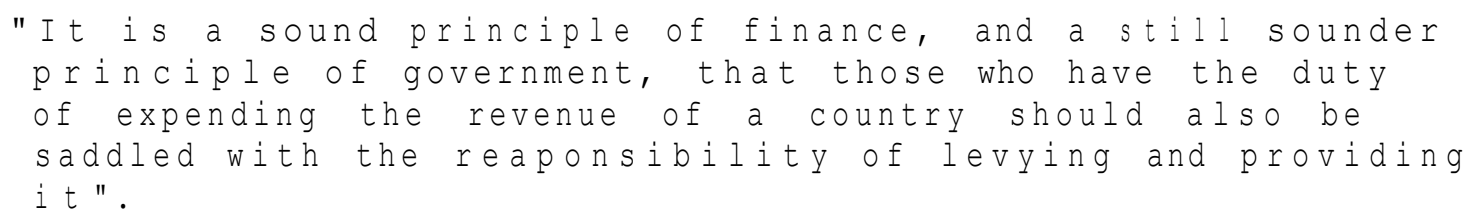

Sir Wilfred Laurier

1. Introduction

It has often been asserted that responsible government requires

a close link be maintained between public spending and taxing decisions.

One of the origins of this view lies in the fact that in the

political marketplace, while votes are the basis of power, they are not

themselves the economic resources which power seeks. The command over

resources comes from the taxing power which is awarded by a majority

of votes. But there is no explicit mechanism in representative demo-

cracies, as Brittan (1974, 1978) and Jay (1976) have recently emphasized,

for ensuring that a majority vote implies a commitment by the voters

of the resources required to finance the program on which a political

party has won an election. By way of contrast to the political market-

place, when individuals plan to acquire more goods or services in the

private market they must each simultaneously commit the resources

required to finance the production of those goods.

In a paper which argued the case for enforcing such unanimity

of decisions in the public market, Wicksell (1896) suggests the absence

of a constitutional link between spending and taxing creates the

*Prime Minister of Canada, 1896-1911. Quoted by Huggett (1977) 
ability for political agents, and voter coalitions, to use an increase in the distance between these decisions as a means of creating (usually) false hopes with respect to the sharing-out function of government, in order to direct additional resources through the public sector and towards themselves. ${ }^{1}$ Making it more expensive to compute individual tax-shares by the failure to simultaneously present tax and expenditure budgets, for example, induces votes for government expansion. For under these circumstances, a promise to reduce the tax-price of public services by shifting part of the cost elsewhere cannot be instantaneously discounted by the decisive voter (Brittan, 1974). However, a reduction in perceived but not actual tax-shares, because the voter is subjectively certain others will bear a larger part of the cost, implies inconsistent demands on the sharing-out 2 function of government. At the very least, therefore, we should expect the gap between perceived and actual tax-shares to narrow over time as the voter, ceteris paribus, comes to the realization that his expectations have not been fulfilled. But also, if adjustment of expectations is slow and public spending increases in size relative to private incomes, because the separation does induce underestimation of tax-shares, the economics of information suggests the voterwill use additional resources in the estimation of his true tax-share. (stigler, 1961$)$.

That there must be some limit to the extent to which information costs can be purposively manipulated, however arrived at, is clear. Otherwise it would not be possible to explain why less than 
100 percent of output flows through the public sector.

Thus, while the temptation for politicians and coalitions to foster the belief that the cost of public services will fall disproportionately on others is obvious, the empirical question is whether, and to what extent, the promises or self-induced hopes that go along with an increase in the separation of spending and taxing can have a systematic and persistent influence on the relative size of government. While information may be equaly possessed by a 1 l agents in stock markets, it may or may not be so in political markets.

In this paper I attempt to shed light on this question by considering a phenomenon which in both Canada and the united states has been associated with one of the most dramatic and increasing separations of the post-war era: the intergovernmental grant from federal to state or provincial governments. If separation, by itself, influences the relative size of the public sector, we could reasonably expect to observe this effect as one of the consequences of the system of intergovernmental flows .

Under the maintained hypothesis that separation reduces perceived tax-shares, and in the context of a voting model, a theory of intergovernmental grants is developed in section two. In this theory, grants exist for the same reason they increase the size of the recipient's public sector; because they represent a promise, not completely discounted by the voter, to shift taxes to other 
jurisdictions. Hence, given an appropriately specified alternative theory, the effect of grants on the budget size of the recipient serves conveniently as a measure of the effectiveness of separation as a means of expanding the public sector. The alternative theory of grants is based on the (alternative) hypothesis that separation does not induce underestimation of tax-shares. A central feature of this theory is that grants are sought by the recipient to effectively block tax-shifting across jurisdictions. It is also outlined in the second section.

The estimating equation used here to test the effect of grants is one that blends the 'pitfalls' literature (Brainard/Tobin, 1968; Smith, 1975) and the empirical voting-model literature (Bergstrom/ Goodman, 1978; McQuire, 1977; Romer and Rosenthal, 1978) to produce a dynamic voting model consistent with a l l relevant cross-equation adding-up constraints. The sample is a pooled time'-series, crosssection set of observations on the Canadian provinces, 1952 to 1969. The estimating equation is developed in section three, and the estimates are reported in section four.

Conclusions are stated in section five. I reject the maintained hypothesis. Evidence from fitting a dynamic decisive-voter model of Canadian provincial decisions does not confirm that grants have a statistically significant effect on expenditures of the representative province. This a startling result in view of the previous econometric literature on the effects of intergovernmental flows, as reviewed by Gramlich (1977). 
5.

2. Using the Political Economy of Federalism to Test the Effect

of the separation of Decisions

Constitutions are rooted in historical time. However, rational they might be, they reflect the milieu and the concerns of a particular era. Over long periods of time these change. Hence there may emerge a shift in roles at the various levels that was not foreseen. In particular, the growth of the welfare state was not foreseen by the framers of either the Canadian-British North America Act or the Constitution of the united states. The central governments in both cases historically possessed the most income-elastic tax revenues, while the local jurisdictions had either historical or constitutional responsibility to satisfy the growing demands for social services.

To a certain extents local (provincial or state) expenditures in the post-war era have been financed by a reassignment of revenue sources, primarily income tax, towards the locality. However, there has also been a rapid growth in federal grants, primarily of the conditional type nominally tied to local provision of social services such at health, welfare and education. " An interesting question is why these intergovernmental flows have arisen, that is, why the provision of social services in the locality has not been financed entirely via reassignment of either revenue sources or expenditure responsibilities.

Under the maintained hypothesis that the deliberate divorce of spending and taxing successfully reduces the voter's perceived taxshare, one possible answer is that vote-seeking local politicians 
(and budget maximizing administrators) favour intergovernmental flows rather than an increase in local taxes precisely because it enables them to avoid taxing directly their own citizens in order to expand expenditure programs. While the need to finance social services is the basic cause of the restructuring of the federation, the effect of separating decisions explains the choice of means. Consider the following example. A representative 'province' will nominally receive a conditional grant of 50 cents from the federal authorities for every dollar it spends on social services. Furthermore, let 25 percent of a 1 f federal tax revenue be collected in the province in question. Thus each additional dollar of provincial social services costs provincial voters 50 - .25 x 50 , or 62.5 cents. Here 12.5 cents represents the federal financing of its 50 cent grant to the province via federal taxes collected in the same jurisdiction. The system of grants seems to have reduced the marginal tax-price of grant-aided provincial expenditures by almost 38 percent, a 'fact'

that provincial governments will hasten to point out.

of course this sort of tax shifting will be recognized and opposed by politicians and voters in other jurisdictions. But under the maintained hypothesis, the voters in this jurisdiction do not believe such reshifting to be effective. In effect, therefore, the system of grants is a promise to the decisive voter in every province to shift tax burdens onto voters in other jurisidctions. 
7.

A reduction in the perceived tax-price would occur regardless of whether the grant was paid conditionally or unconditionally. An unconditional grant of one dollar appears to cost the provincial taxpayer 25 cents. Hence even if these grants were in fact (but were not perceived to bel entirely financed by federal taxes levied in the province in question, because reshifting was complete, expenditures will be increased beyond that which would occur were they financed directly by the province itself.

The econometric literature on the effects of grants on local expenditures, as reviewed by Gramlich (1977), seems to indicate precisely 7

this latter result. The evidence is that the positive effect on local spending of an unconditional grant outweighs the negative impact of an equivalent increase in federal taxes. Indeed, the conclusion that 'money sticks where i t hits' (the grant is not entirely returned to the voter via local tax cuts) was so uniformacross various studies that Gramlich called for development of theory to explain the phenomena.

At this point it is important to acknowledge that grants are the outcome of interaction between two levels of government. As Breton and Scott (1978) have argued, a theory of these grants must therefore be compatable with the self-interest of political agents of both 9 recipient and donor jurisdictions. I have so far dealt only with the incentives of local politicians, arguing that under the maintained hypothesis they favour grants rather than own taxation because this enables them to avoid taxing their own voters directly. It seems 
8.

reasonable to argue, on the other hand, that the federal politician desires this because he can then obtain the credit of being a co-provider of social services along with his local counterpart. This would explain why grants are primarily of the conditional type which carry with them some identification of the donor with benefits received. The alternative is to allow other jurisdictions to be seen as the sole provider of social services, the single most rapidly growing area of the public sector.

Breton and scott also regard a grant as the by-product of an exchange between donor and recipient jurisdictions. In their model a revenue-rich federal government buys functions from a revenue-poor 'province'. "Hence, as in the present model, the purpose of the grant is not related to the form it takes, and may never be popularly known; conditional grants are not necessarily meant to alter the composition or size of provincial expenditures. However, Breton and Scott do not explain why the province, with constitutional access to income taxation, finds i t profitable to sell a function to the feds rather than raise their own tax rates. After al l, votes are not lost by financing public services for which there is a growing demand. One answer, given above, is the ability of political agents to benefit from the larger budget induced by the effect of grants on perceived tax shares. 


\section{9 .}

2.1 Alternative Hypotheses

The assumptions underlying the theory of grants developed

above are essentially twofold. First, the maintained hypothesis, that an increase in the separation of spending and taxing decisions such as grants create is sufficient to reduce perceived tax-shares. Second, the existence of grants results from collusion between political agents of donor and recipient jurisdictions to take advantage of the effect of grants on voter perceptions.

I seek as an alternative theory of the existence and effect of grants, one which predicts grants will have no effect on budget size in the recipient jurisdiction, at leastin partbecause the first of the above assumptions is false.

It turns out that by dropping the second of the above assumptions, such a theory can be developed. This alternative theory is not rejected by casual observation, and it too is consistent with Breton and scott because it supplies a different reason for grants to arise as the by-product of some exchange between donor and recipient. Traditional theoriesinvolve externalitiesorredistribution. For example, and ignoring the redistribution motive for the moment, the presence of imperfect mappings, to use Breton's (1965) term, between the range of benefits of non-private goods and the jurisdiction buying the good implies grants are required for the attainment of Pareto efficiency. A local jurisdiction that produces public services with benefits that spill over into other jurisdictions will produce less than a pareto-efficient quantity. The remedy is conditional 
grants from a higher level of government to stimulate production. But Schumpeter (1942) would probably reject the externality based theory of the existence of grants for the same reason he rejected the classical political theory; because i t implies the attainment of a social goal (pareto efficiency) motivates individual political 12 agents. In a theory which is consistent with utility maximization by individual political agents, grants shouldarisenaturally as a

by-product of the competitive struggle for political power. Moreover, in the context of a voting model, Isserman (1976) has shown why the theory of externalities does not provide a firm basis for the direction of grants from central to local government. The reason is that in a voting model, the local production of the externali generating public service depends upon demands by the decisive voter in that jurisdiction. If he has a 'high' demand, i t is possible that too much will be provided, rather than toolittle. Therefore the mere existence of external effects does not allow us to predict the emergence of a system of grants from higher to lower government levels.

To develop an alternative theory of grants without either of the above faults, I begin by accepting the provious explanation for 14

the federal (donor's) interest ingrants. The federal authorities, then, wish to buy, or force, their way into the system of social services using grants, because these services are constitutionally or historically controlled by the province or state. Now suppose 
11.

that the federal government makes an offer to each 'province' separately to finance part of its social system. In effect, this is an offer to tax other provinces to pay for grants to this province. If other provinces do not take up the offer, the grant will, and will be seen to, lower actual tax-prices in this province, while raising it in others. But tax-shifting (to be distinguished from redistribution acceptable to recipient and donorl, like other forms of discriminiation, must contend with the reactions of those discriminated against (Stigler, 1970). Every province must and will accept the federal offer. Since tax-shifting is then prevented, and because by assumption the separation of decisions that is created by the system of grants has no effect on perceived tax-prices, provincial 14

decisions remain unaltered. The only purpose and effect of the grant system is to allow the federal government to force its way into the provincial fiscal system, by placing each province in the 15

prisoner's dilemma discribed above. From this point of view, for example, the federal offer to share with the privinces in Canada 50 percent of expenditures on their major social service items (medicare, hospitals, post-secondary education, welfare) is understandable. A uniform 50 percent federal contribution to encourage the production of spillovers is not.

Strictly speaking, this theory is complementary to the traditional theory based on the redistributionmotive. This explanation of grants begins with a desire to reduce differences in per-capita taxable 
capacity of different regions. These differences lead to individuals in similar economic circumstances, but living in different jurisdictions bearing different tax burdens or enjoying disparate levels of public services. In this view, transfers from richer to poorer regions arise to prevent unequal treatment of similar individuals in different 16

regions.

For purposes of this paper, I can accept the possibility of a redistribution motive for grants without compromising the test of the maintained hypothesis. It does not matter that the theory of grants based on theresistributionmotive as stated here appears to be independent of the self-interest of the political agents who 17

organize them. What is important about the redistribution motive in the present context is that if grants exist to perform this function, tax-prices will, and will be seen, to change. Voters in receiving jurisdictions will find their tax-prices lower than they would be in the absence of such grants, and consequently we should observe more spending there, than in absence of this redistribution. on the other hand, spending in the contributing jurisdictions should be lower. Putting the redistribution theory together with the prisoner's dilemma model outlined above implies that grants will have no effect unless they are intended, by recipient and donor, to redistribute amongst themselves. This is in contrast to the theory based on the maintained-hypothesis, which predicts an expansion of expenditures by the representative local government receiving the grant, even if 
the grant is entirely financed there.

Hence, a test of the effect of grants on local expenditures can be viewed as a convenient test of the hypothesis that the separation of decisions grant create reduces preceived tax-shares.

\section{The Estimating Equation}

To begin formal development of an estimating equation, assume that the representative local political agent acts as if he maximizes the utility of the decisive voter in his jurisdiction. The arguments of this voter's utility function are his perceived public services $q$ and his perceived disposable income (other goods and services)y. If this utility function, following McGuire: (1975, 1977), is of the Stone-Geary type, it can be written as 18

(1) $\beta q$ in $\left(q-\gamma_{q}\right)+\beta y$ in $\left(y-\gamma_{y}\right)$

where $q=\theta_{1} Q$ and $y=x-\theta_{2} R-\theta_{3} G_{T}$.

Here $Q$ and $R$ are respectively total (actual) provincial expenditures and total (actual) revenues from own sources. $x$ is the voter's gross income, assumed known to him with certainty, and $G_{T}$ is the total value of grants to all provinces.

The $\theta_{i}$ 's translate fiscal aggregates into quantities relevant to the decisive voter. They are regarded here as unknown parameters. $\theta_{1}$ and $\theta_{2}$ represent the decisive voter's preceived per dollar share of public services and tax revenues respectively. ${ }^{19} \theta_{3}$ represents the voter:s perceived per dollar share of federal taxes required to pay 
for the system of grants in the country as a whole. The voter's perceived level of services is therefore $\theta_{1} Q$, while his perceived disposable income is $x-\theta_{2} R-\theta_{3} G_{T}$. His perceived tax-price is $\left(\theta_{2} R+\theta_{3} G_{T}\right) / \theta_{1} Q$.
$\quad \gamma_{y}$ and $\gamma_{q}$ give the origin of the utility map, and following Pollack and wales (1978) are regarded as normalizing variables. The natural presence of these normalizing factors (also called survival bundles) makes the Stone-Geary function particularly attractive when using a pooled time-series, cross-section sample, as I do below.

The agent maximizes the above utility function over $Q$ and $R$ subject to the government budget restraint (2) $R+G=Q$, where $Q$ is assumed to have constant unit cost of $\$ 1.20$.

It is important to note that (2) does not embody any distinction between conditional and unconditional grants. This is consistent with the theory of grants based on both maintained and alternative hypotheses. In the theoretical framework of the present paper, the only reason for conditional grants from the viewpoint of the federal authorities is to associate themselves with the local social service system. Whether the grants are in fact spent on those items to which the grants are nominally tied is not of interest to them, though they may say it is. No serious objections would be forthcoming if the recipient, via judicious accounting procedures, transformed conditional grants to unconditional so as to gain additional degrees of freedom. 21 
And these procedures are necessary only to the extent that the recipient would not have made the same expenditure in the absence of the grant, since otherwise all grants are effectively unconditional. Maximization of (1) is also subject to institutionalized arrangements particular to the theories developed above and to the sample used below, which make the conditional grants $G^{C}$ a relatively stable function of $Q$. I assume this is of the simple form: (3) $G^{C}=f(Q)$, where $G^{\mathrm{C}}=G-G^{\mathrm{U}}$ and $G^{\mathrm{U}}$ is the unconditional grant component of $G^{22}$ Although (3) does not imply the federal government wishes to stimulate production of public services at the lower level, it is known and given to local governments, and therefore will be incorporated into their optimal political plans along with (2).

The first order conditions give the following equation for total provincial expenditure:

(4) $Q^{*}=\omega X+\omega\left(\theta_{2}-\theta_{3}\right) G+\left(-\omega \theta_{3}\right) \tilde{G}+\omega^{-} \gamma_{y}+\omega^{-\prime} \gamma_{q}$ where $G^{C}$ has been kept on the right-hand side rather than eliminated by substitution of (3). 23 The analogue for $R^{*}$ need not be stated here. In (3), $\tilde{G}$ represents grants to all provinces except this one, hence $\tilde{G}=G_{T}-G$.

I am primarily interested in the size of $\theta_{2}$ relative to $\theta_{3}$. When $\theta_{2}>\theta_{3}$, a grant will increase desired local expenditure even if it is in fact entirely financed within the locality in question. Figure 1 illustrates this case. Here the voter's perceived level of 
16.

services $q$ is on the horizontal axis and his perceived disposable income $y$, is on the vertical. The line $\left[x, \theta_{1} / \theta_{2} \cdot x\right]$ represents the possible combinations of $y$ and $q$ such that $R=Q$. If the 'province' in which this voter lives now reduces taxation from own sources by $G$ dollars, the federal government increases taxes in the province by $G$ dollars, and returns this in the form of an unconditional grant of the same amount, the possible combinations of $y$ and $q$ such that $R+G=Q$, shifts out as indicated. Since the stone-Geary utility map has a linear expansion path, equilibrium for the government moves from $E$ to $E^{\prime}$, where the provision of public services has been expanded by $B A / \theta_{1}$.

If grants are not perceived as a means of shifting taxes to voters of other jurisdictions, that is if $\theta_{3}=\theta_{2}$, they cannot have a real effect in the present voting model, except perhaps to waste resources in administration. It does not matter whether the grant is paid conditionally or not as I have pointed out above; the vital issue in the end is where the voter thinks the federal share is financed. Therefore, if we find that grants do not in fact lead to a change in expenditure by the representative jurisdiction receiving grants, we can conclude $\theta_{2}=\theta_{3}$ on the average, and clearly the separation of decisions grants create cannot have ween responsible for an increase in the size of the public sector. 
The Effect of an Unconditional Grant Entirely

Financed in the Recipient Jurisdiction, When $\theta_{2}>\theta_{3}$

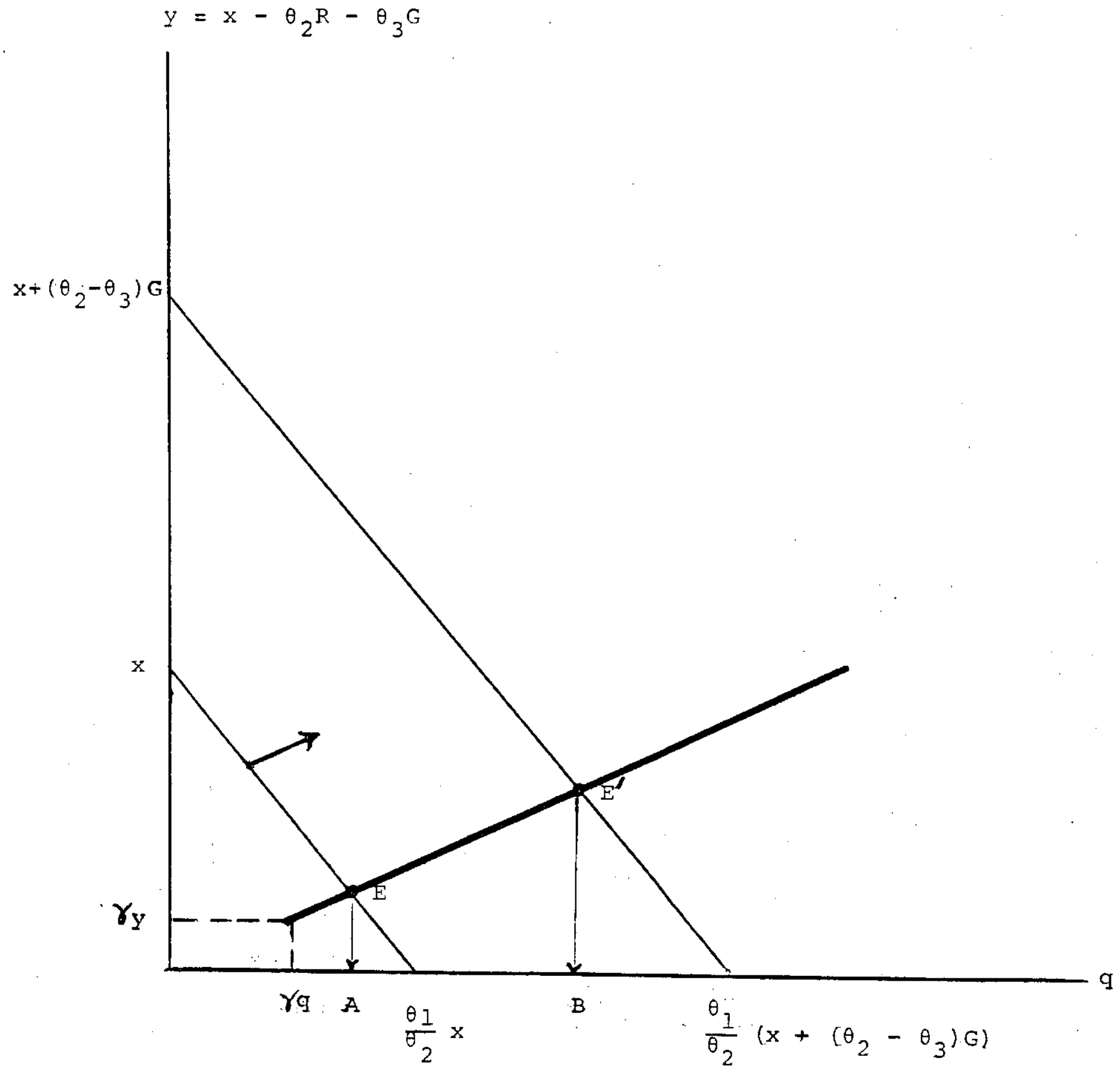


3.1 A Dynamic Formulation and other Considerations

Equation (4) defines the recipient government's desired level of public services, $Q^{*}$. But there is no reason to assume that a government will adjust to its politicaliy optimal plan within each period. The voter's estimate of $\theta_{2}$ and $\theta_{3}$ may well be more accurate the faster his tax burden increases. In that case a government interested in maximizing the size of the public sector will trade off a smalier public sector in the short-run for a larger long-run equilibrium size. At the very least, we should expect some recognition and administrative lags following changes in gross incomes or demographic factors.

I choose the following dynamic version of equation (4):

$$
Q=\alpha Q^{*}+\delta \Delta G+(I-\alpha) Q_{-I} \text {. }
$$

The equation for $R$ is then given by $R=\varepsilon Q^{*}+\mu \Delta G+(I-\varepsilon) Q_{-I}$. In (5), the impact effect on expenditure of an increase in grants to the representative province is equal to $\gamma \omega\left(\theta_{2}-\theta_{3}\right)+\delta$, while the long-run effect is given by $\omega\left(\theta_{2}-\theta_{3}\right)$.

As is well known (Brainard/Tobin, 1968; Smith, 1975; Sparks) a simple stock adjustment version of the two first-order conditions for $Q$ and $R$ implies instantaneous adjustment of both variables. The reason is that the left-hand side variables $Q$ and $R$ in the two equation system:

$$
\begin{aligned}
& Q=\alpha Q^{*}+(1-\alpha) Q_{-I} \\
& R=\varepsilon R^{*}+(1-\varepsilon) Q_{-I}
\end{aligned}
$$


must satisfy the budget restraint (2). But only with $\alpha=\varepsilon=1$ will equations (6) satisfy the cross equation adding-up restraints implied by (2), which are that (i) with G. fixed, an increase in $Q$ for any reason must be accompanied by an equal increase in $R$, and (ii) an increase in $G$ must be exactly distributed in a combination of higher $Q$ and lower R. Equation (5) is a non-trivial dynamic version of (4) which satisfies both restraints. 24

To cope with multicollinearity of the variables in (5) it proves necessary to use a pooled time-series, cross-section sample of jurisdictions. 25 In particular, this requires the $\theta_{i}$ 's to be identical across jurisdictions. An assumption which yields this result is that perception of expenditure and tax shares is highly correlated with the position of the voter in the national income distribution, which is the same for the decisive voter in each jurisdiction. Note that this implies $\theta_{3}$ does not depend on the extent to which a particular jurisdiction receives redistributive transfers. $G_{T}$ is financed via federal taxes, and the perceived incidence of these taxes is assumed to be similar for voters in different jurisdictions who have approximately the same incomes.

Finally in order to convert (5) into an estimating equation, I assume the normalizing factors take the form.

$$
\begin{array}{ll}
\gamma_{j t}=\gamma_{j}^{0}-\gamma^{1} N_{j t} & j=1, \ldots, \mathrm{J} \\
\gamma_{q_{j t}}=\gamma_{j}^{2}-\gamma^{3} N_{j t} & t=1, \ldots, \mathrm{T}
\end{array}
$$


where $\mathrm{N}_{j t}$ is the population of a jurisdiction receiving grants, $J$ is the number of such jurisdictions and $T$ is the number of time periods.

Substituting (4) and (7) into (5) and rearranging terms gives the estimating equation:

$$
\begin{aligned}
Q_{j t}=\beta_{0} x_{j t}+\beta_{I} G_{j t}+\beta_{2} \tilde{G}_{j t}+\beta_{3} \Delta G_{j t}+\beta_{4} Q_{j t-1} \\
+\beta_{5} N_{j t}+\Sigma \beta_{6 j}+e_{j t,}
\end{aligned}
$$

where $\beta_{0}=\alpha \omega, \beta_{1}=\alpha \omega\left(\theta_{2}-\theta_{3}\right)$ and $\beta_{2}=-\alpha \omega \theta_{3}$.

It is assumed that the errors $e_{j t}$ have zero mean, are homoscedastic for given $j$, and are both serially independent and independent across jurisdictions. It is not necessary to assume that $v\left(e_{j t}\right)=v\left(e_{k t}\right)$, for all $j \neq k$.

This equation differs from those used in other studies of the effects of grants (for example, Henderson, 1968 and Gramlich, 1969 in the U.S., Hardy, 1976 and Alld, 1976 in Canada) principally because of the presence of $\tilde{G}_{j t,} \Delta G_{j t}$ and $Q_{j t-1}$ as explanatory variables. The first of these variables is present because we have explicitly considered the financing of grants by the donor, while the latter two enter because we do not assume instantaneous adjustment by political agents.

All variables in (8) are in real terms, and except for $G_{j t}$ and therefore $\Delta G_{j t}$, are assumed to be predetermined at time $t$. $G_{j t}$ is endogenous because of equation (3) which makes $G_{j t}^{C}$ a function of $\theta_{j t} \cdot{ }^{26}$ 
We proxy $x_{j t}$ ' the income of the decisive voter, by $n x_{j t}^{l}$, where $\eta$ is an unknown positive constant and $x_{j t}^{l}$ is per capita income in the province. Recent work by Romer and Rosenthal (1978, 1979) casts doubt on the propositions that the decisive voter is the median voter, and that this voter has medium income. However, it is sufficient in the present context that there be a decisive voter lor else a representative of the decisive group) whose income is highly correlated with average income. At what fractile of the income distribution this voter is does not matter, even though the $\theta_{i}$ in (8) are then known only up to an unobservable constant, $\eta$. The reason is that we are interested only in $\theta_{2}$ relative to $\theta_{3}$, that is, in the $\operatorname{sign}$ of $\beta_{1}$ in (8). Identification of $\theta_{2}$ and $\theta_{3}$ by themselves is not required. of course, we must also assume $n$ is constant for all $j$ and $t$.

\subsection{Choice of Estimator.}

Since equation (8) is part of a three equation system consisting of (8), the analogous equation for $R_{j t^{\prime}}$ and the budget restraint (2), estimation of (8) must preserve the cross-equation adding-up constraints mentioned above. As is well-known, a two-stage technique in which the identical set of explanatory variable appears in each equation, which is the case here, and in which instrumental variables are the same for each first-stage regression, will produce consistent estimates under these conditions. 27

Moreover, because (8) and the complement for $R_{j t}$ are derived from the same maximization problem, they constitute a set of seemingly 
unrelated regressions (Zellner, 1962). However, the two-stage procedure above will allow for contemporaneous cross-equation correlation of residuals because it is equivalent, in the present case, to three-stage estimation of the entire (2 equation) system. There are two ways to see this. First, since the equation for $Q$ and that for $R$ are seemingly unrelated, the residuals in these equations sum to zero for each $t$. Thus one equation must be aropped from the system before generalized least squares can be employed, to avoid singularity of the variance - covariance matrix. 28 Thus with only two equations in our system, generalized least squares can not be used to improve the efficience of the two-stage estimators. Alternatively, one can note that because each equation in the system has the same set of explanatory variables, two and three-stage estimators are identical (Srivastava and Tiwari, 1978). This result is a straightforward extension of the equivalence of OIS and GLS in the same circumstances first noted by zellner.

\section{Results}

To estimate (8) I have used a pooled time-series, cross-section sample of observations on the Canadian provinces. The main sample period extends from fiscal year 1952 to fiscal year 1969.29 A rough test supported the pooling of data for this period. 30

Table 1 gives results for this sample period and for several subperiods. 31 Under the maintained hypothesis, $\hat{\beta}_{1}$ in (8), the coefficient on $G$, should be positive and significant. However, the 
results (see row 2) clearly do not support the conclusion that grants increase spending in the representative province. It would appear that the decisive voter in the representative province does not regard federal taxation levied to pay for the system of grants as less 'onerous' than provincial taxation, either on average or at the margin.

On the other hand, these results show $\hat{B}_{2}<0 ;$ grants $\tilde{G}$ to other provinces, which are partly financed by federal taxation in the representative province, clearly result in a lower perceived disposable income and hence less spending in that province (row 3 ). While grants do not appear to have an effect on the representative province, they may still have an effect on particular provinces if they are net recipients of, or contributors to, a system of equalization payments. In this case, the system of grants should result in more spending in the recipient provinces, and less in the donor provinces.

Table 2 indicates that this is precisely the case in the Canadian federation. For the maritime provinces, all net recipients under the Canadian system of equalization payments (Young, 1977), $\hat{B}_{1}$ is positive and significant at 90 percent (with one exception) while $\hat{B}_{2}$ is not significantly different from zero. The later result indicates that the maritime voter does not regard himself as contributing anything of significance to other provinces. For the net contributors to the equalization system, Ontario, Alberta and British Columbia, 
$\hat{\beta}_{1}$ is not significant at $90 \%$ while $\hat{\beta}_{2}$ is negative and significant (with one exception). Hence it seems reasonable to conclude the representative voter here regards grants to his province as being essentially financed within the provinoe, while grants to other provinces (especially the maritimes) are regarded as a significant drain on his disposable income. It is of interest to compute what the level of expenditures in these two groups of provinces would be in the absence of the system of grants. Letting $A$ be average provincial expenditure for the group in the absence of the grant system, we can use

$$
\text { (9) } \frac{Q}{Q}=\frac{A}{Q}+\hat{B}_{1} \frac{G}{Q}+\hat{B}_{2} \frac{\mathcal{G}}{Q}
$$

to give us a rough estimate of the average impact effect of the system of grants. ${ }^{32}$ Here all variables are to be interpreted as averages over each of the two groups of provinces in Table 2. Note that the term in $\Delta G$ is anitted fron (9) because $\hat{B}_{3}$ is not significant in Table 2 for either group.

Setting $\hat{B}_{i}=0$ if insignificant, and substituting the appropriate means, for the sarmle period in Table 2 we find for the maritimes

$$
1.26<\mathrm{A} / \mathrm{Q}<1.47
$$

For the combination of the three richest provinces,

$$
0.71<\mathrm{A} / \mathrm{Q}<0.83
$$

Thus the system of grants has increased spending in the maritime provinces by at least 26 per cent on the average, while on the average it has reduced spending in the richest provinces by at least 17 per cent. ${ }^{33}$ 


\section{Conclusions}

The empirical question dealt with in this paper is whether the premises or self-induced hopes about tax-shifting that go along with an increase in the separation of spending and taxing decisions can have a systematic and persistent influence. Information may be equally possessed by a 1 l agents in stock markets, but it may or may not be so in political markets.

To shed light on this issue, I have considered a situation which has led to one of the most dramatic and increasing separations in the post-war era: the intergovernmental flow from federal to state or provincial governments. Under the maintained hypothesis that separation reduces perceived tax-shares, a theory of intergovernmental flows was developed. In this theory grants exist for the same reason they increase the size of the recipients' public sector; because they represent a promise, not completely discounted by the voter, to shift taxes to other jurisdictions. Thus, in this theory, the effect of grants on the budget size of the recipient serves conveniently as a measure of the effect of separation on perceived tax-shares. However, evidence from fitting a dynamic decisivevoter model of Canadian provincial decisions does not confirm that grants have any effect on expenditures of the representative province.

The alternative theory that survives the test is one in which grants not meant to redistribute between regions represent the working out of a prisoner's dilemma, forced upon the 'provinces' by the federal government. In this theory, provincial governments must and do accept grants in order toeffectivelyblock tax-shiftingacross jurisdictions. But insodoing they allow the federal authorities to associate themselves with the provision of social services, the single most important area of public sector growth, and one in which the provinces have the primary constitutional 
25.

or historical responsibility.

obviously some separation of spending and taxing decisions is necessary before any tax-shifting is a possibility. But the success of the alternative theory of grants suggests that an increase in separation does not necessarily lead to excessive expectations with respect to redistribution via the fiscal system, by obscuring the true relative cost of public services. This is turn raises the question of what conditions are sufficient to generate a demand for redistribution via the fiscal system that exceeds the supply. 
IABLE I

2S1s Estimates of Enuatlon (8): A Dynamle Model of Real Total Provinclal Expend lture?.

\begin{tabular}{|c|c|c|c|c|c|c|c|c|c|}
\hline & & $\begin{array}{r}57.69 \\
+\quad \text { OUE } \\
\end{array}$ & $52-69$ & $\begin{array}{r}56-69 \\
+ \text { QUEE } \\
\end{array}$ & $56-69$ & $\begin{array}{r}56-67 \\
+\quad \text { OUE } \\
\end{array}$ & $56-67$ & $\begin{array}{r}61-69 \\
+0 \text { UIE } \\
\end{array}$ & $6.1-69$ \\
\hline$x^{\prime}$ & $\therefore$ & $\begin{array}{l}62.7 \\
(3.54)\end{array}$ & $\begin{array}{l}60.8 \\
(3.37)\end{array}$ & $\begin{array}{l}95.9 \\
(4.11)\end{array}$ & $\begin{array}{l}91.4 \\
(3.65)\end{array}$ & $\begin{array}{l}88.1 \\
(3.51)\end{array}$ & $\begin{array}{l}90.2 \\
(3.84)\end{array}$ & $\begin{array}{l}83.5 \\
(2.19)\end{array}$ & $\begin{array}{l}75.1 \\
(1.96)\end{array}$ \\
\hline$G$ & & $(1.22)$ & $\begin{array}{r}.102 \\
(1.17)\end{array}$ & $(1.04)$ & $\begin{array}{r}.119 \\
(.67)\end{array}$ & $(.1 .61)$. & $\begin{array}{r}.173 \\
(1.19)\end{array}$ & $\begin{array}{l}.008 \\
(.291)\end{array}$ & $\begin{array}{l}.138 \\
(.166)\end{array}$ \\
\hline $\overrightarrow{\mathrm{s}}$ & & $\begin{array}{r}-.018 \\
(-3.28)\end{array}$ & $\begin{array}{r}-.017 \\
(-3.03)\end{array}$ & $\begin{array}{r}-.028 \\
(-3.61)\end{array}$ & $\begin{array}{r}-.026 \\
(-3.00)\end{array}$ & $\begin{array}{r}-.028 \\
(-3.50)\end{array}$ & $\begin{array}{r}-.024 \\
(-3.22)\end{array}$ & $\begin{array}{r}-.018 \\
(-1.09)\end{array}$ & $\begin{array}{r}-.016 \\
(-1.10)\end{array}$ \\
\hline$\Delta G$ & & $\begin{array}{r}-.181 \\
(-.67)\end{array}$ & $\begin{array}{r}-.300 \\
(-.88)\end{array}$ & $\begin{array}{l}.021 \\
(.05)\end{array}$ & $\begin{array}{r}-.167 \\
(-.31)\end{array}$ & $\begin{array}{r}.630 \\
(1.47)\end{array}$ & $\left(\begin{array}{l}.359 \\
(.70)\end{array}\right.$ & $\begin{array}{r}-.502 \\
(-1.09)\end{array}$ & $\begin{array}{r}-.650 \\
(-1.10)\end{array}$ \\
\hline $0_{-1}$ & & $\begin{array}{r}1.00 \\
(20.6)\end{array}$ & $\begin{array}{r}1.00 \\
(18.0)\end{array}$ & $(10.5)$ & $\begin{array}{r}.952 \\
(8.87)\end{array}$ & $(6.14)$ & $\begin{array}{r}.776 \\
(5.07)\end{array}$ & $\begin{array}{r}.905 \\
(6.16)\end{array}$ & $\begin{array}{r}.913 \\
(6.08)\end{array}$ \\
\hline$R^{2}$ & & .992 & .991 & .997 & .991 & $.9 b n$ & .989 & .990 & \\
\hline SEE & & .405 & .410 & .117 & .132 & .121 & .100 & .512 & .543 \\
\hline$d f$ & & 164 & 147 & 124 & 111 & 101 & 93 & 74 & 66 \\
\hline
\end{tabular}

See Notes to Tables and Appendix. Deflnition of Varlablese $x^{\prime}=$ real per caplta income, G = real total grants to thls province, $G=$ real carants to other provinces, $\quad \mathrm{g}=$ lirst difference in $6,0_{-1}=0$ lagged one pertor.

Sunmary statistles: $R^{2}$ is inadlusted, SEE is the standard error of eritlimate, ill are the degrees of lreedem apropitate for the t statlstics glven in lirackets. 
IABI.E 2

The Red tstributive Effects: of Cederal Grants to the. Provinces

Marltimo Provinces (Reclplents) Ontarlo, Niberta, British Columbla (1)onors)

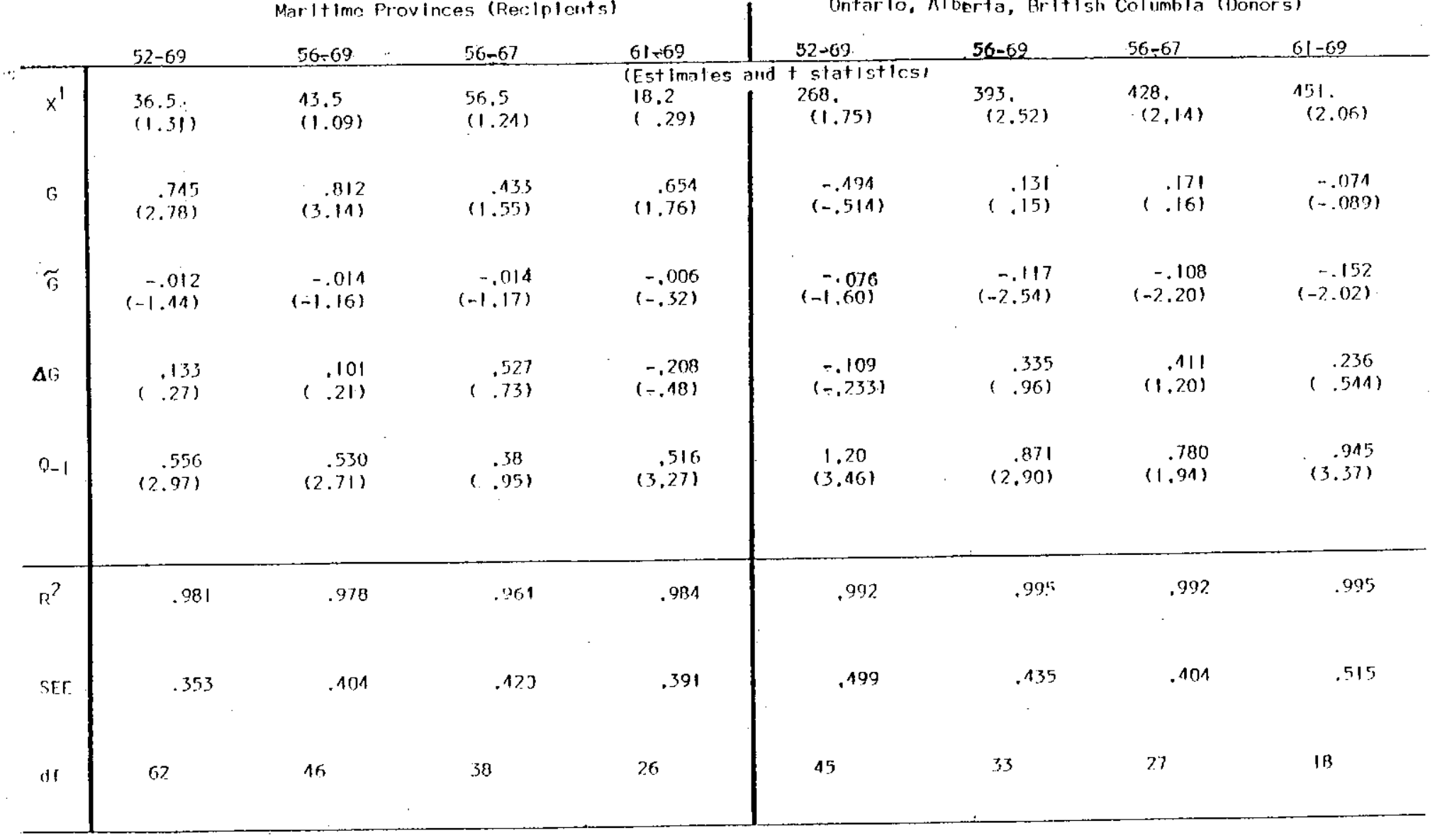


NOTES TO TABLES

1. Sample periods are for fiscal years ended nearest December 31 of the years named.

2. Coefficients on constant terms, population and provincial dummy variables are not reported. Generally speaking, all provincial dummy variables are significant at the 90 percent level.

3. Instrumental variables include all predetermined variables in equation (8) as well as lagged per capita income, lagged total grants, lagged unconditional grants, and a shift variable which steps in the fiscal year following renegotiation of federal-provincial economic arrangements. 
1. Wicksell (1896), especailly pp 86-87 and 91. This view should be distinguished from Wicksell's argument in the same paper, that a system of unanimity and voluntary consent in public taxation might on balance lead to an increase in the aggregate size of the public sector.

2. The difference between actual and perceived tax-shares (or tax-prices) has been referred to as 'fiscal illusion.' For a review of the fiscal illusion literature, see West and Winer (forthcoming).

3. The discussion applies equally well to grants fromprovincial or state to municipal government, though that case is not considered here.

4. Conditional grants have been far more important than unconditional grants since 1945 in both the U.S. and Canada. See, for example, Pommerehne $(1977,336-7)$. Excluding tax revenue collected by the federal government on behalf of lower levels, the ratio of conditional to unconditional grants in Canada in 1970 was 2.6 to 1. In the United States in 1970 there were no unconditional grants. However, it is important to recognize that tied grants may be conditional only in name, particularly when the recipient does not alter total spending, or does make appropriate alterations in accounting procedures.

5. I am ignoring for simplicity that sharing of this total tax burden amongst individuals in the province.

6. It is of interest to note that there is some evidence the pioneers of the Canadian constitution in the I860's recognized the dangers and tried to forestall them. Thus spoke Alexander Tilloch Gait (Minister of Finance) in the 1865 Legislative Assembly: "If the 
men in power find that they are required, by means of direct taxation, to procure the funds necessary to administer the local affairs, for which abundant provision is made in the scheme, they will pause before they enter upon any career of extravagance..." (from P.B. Waite, 1963, p. 54$)$.

7. Gramlich (1977, p. 234).

8. Of course this suggests the cited evidence is not definitive. See Gourant, Gramlich and Rubinfeld (1978) for an explanation of this result related to that presented here. Their argument relies on mispercaption of the magnitude of grants, rather than false expectations concerning tax-shifting.

9. See A. Breton and A. Scott (1978, chapter 12).

10. Both federal and local bureaus would also favour conditional over unconditional grants because the former lead to greater administration cost. The model might be further fleshed out as follows: The federal politician (and federal administrator) would probably prefer a reassignment of expenditure responsibilities from the'province* to the federal level, but the provincial politician will enforce his constitutional or historical responsibility for social services if at all possible or risk losing identification with the single most important area of government growth in the post-war period. Enforcement of the constitutionis also in the interests of the provincial bureau, since otherwise it loses control over a provision of a very significant part of public expenditures made in the province. For the same reasons, federal grants are made to provincial governments rather than individuals. (A recent illustration of this last point 
is contained in the U.S. bureaucracy's response to pressure for a voucher system in education. See E.G. West (1980).

11. The theory does not predict the extent of collusion amongst the jurisdictions receiving grants.

12. Breton and Scott have also rejected the traditional externality theory of grants, though not for the reason given here. Their argument is based on the absence of transactions costs in this theory.

13. Of course, this does not mean the system of grants can never contribute toward social welfare.

14. Since the federal government is then subsidizing expenditures in each province, the marginal tax-price of grant-aided public services is reduced there, given the behaviour of all other provincial governments. But this does not lead to greater provincial expenditures in the present case, because the behaviour of other provinces is not thought to be invariant with respect to attempts at taxshifting via the grant system.

15. There may be other theories of grants which do not assume it is impossible for the jurisdictions receiving grants to collude, but which yield the same conclusions regarding the effect of grants (none). I do not consider them here. I have chosen the prisoner's dilemma formulation because it seems to $f$ i t the cases of Canada and the U.S., in which no arrangements exist to prevent tax-shifting via the grant system if a particular province or state should wish to abstain from participation. Only in Canada is there a mechanism, called the 'opting-out formula,' that compensates abstaining provinces according to what they would have received had they stayed in (see 
Smiley, 1971, for the details). But clearly 'opting-out' will not protect a province against adverse shifting because sore other province unilaterally increases its expenditures on the grant-aided comodity. Entry into the program may be required as a signal that such an event would be resisted.

16. The nomative theory of the redistributive unconditional grant has been considered by Buchanan (1950), Graham (1964), Musgrave (1961), and Scott (1964). Redistribution via conditional grants is discussed by Feldstein (1975) in the U.S., and Young (1977) in Canada amongst others.

17. Bretan and Scott (1978, chapter 10) have attermpted to develop a theory of redistributive grants in a public choice context.

18. See Green (1971, chapter 9) for the properties of the Stone-Geary utility function.

19. $\theta_{1}$ in the present model is equivalent to $1 / \mathrm{N}^{\alpha}$ in the Borcherding/ Deacon (1972) and Bergstram/Goodman (1973) models, where $N$ is population and $\alpha$ is the degree of publicness parameter. It is interesting to note, however, that the present formulation suggests $\alpha$ is not identifiable for the following reason. Let $q=Q / N^{\alpha \beta}$, where $\beta$ is the 'sharing' parameter, $0<\beta<\infty$. Then $\alpha=\beta=1$ implies $Q$ is a pure private good equally shared. Borcherding-Goodman estimated $\alpha . \beta$ and concluded that $\alpha=1$, but clearly this assumes $\beta=1$. It could be that $\alpha<1$ but not equal to zero, that the private component of $Q$ is shared unequally so that $\beta>1$, and also that $\alpha . \beta$ is approximately 1 . It does not seem possible to distinguish the degree of publicness of a good from the degree to which a private good is equally shared. 
30.

20. An alternative formulation (see for example Bergstrom/Gocdman, 1973) is to maximize the decisive voter's utility subject to his budget restraint. The government budget restraint is then enforced by the condition that individual tax-shares sum to one. The procedure used here enforces the government budget restraint explicitly, and is formally equivalent to the alternative method. However, in the present context it is more convenient.

21. One method would be to redefine expenditures so as to broaden the grant-aided category. Thus an increase in expenditures on the (redefined) grant-aided commodity may signify the successful conversion of conditional grants to unconditional form, while a naive model would consider the conditions to have been effectively binding.

21. See McQuire (1975) for an extensive list of other methods. Strick (1971) in Canada, and McQuire (1977) and Johnson and Tomola (1977) in the U.S. have concluded that for the particular cases they considered, conditional grants were effectively transformed to unconditional ones.

22. Most conditional grants are equal to .50, but I could also allow them to depend on population, cross-section dummy variables, or discreet changes in federal-local agreements, without loss of generality. The reason is that only the dependence of $G$ on $Q$ matters in the derivation of the first order conditions.

23. Substitution of (3) does not seem wise because some of the recipients in the sample used here received only very small unconditional grants which varied little over the sample period. It seems preferable to leave $G$ in (4) and use a simultaneous estimation technique. Moreover, it turns out that a test of the maintained hypothesis using the 
reduced form for $Q$ requires the estimation of the coefficient of $Q$ in the linear version of (3). But when the reduced form for $Q$ is substituted back into (3) so as to derive the reduced form for $G^{C}$, this coefficient becomes unidentifiable. A simultaneous estimation technique is thus unavoidable, and so it seems preferable to estimate (8). rather than (3) in this way.

24. This is analogous to Smith's equation (3). The term in $\left(R^{*}-R_{-I}\right)$ has been eliminated using equation (2).

25. Results of a test of this assumption are reported below.

26. $G^{u}$ will be predetermined at $t$, according to the fonmula by which they are computed in the sample used here (see for example courchene and Beavis, 1973) as long as $x_{t}$ does not depend on $Q_{t}$.

27. See Smith (1975, pp. 515-6).

28. The remaining estimates can be determined residually using the adding up constraints ( Smith, op. cit) Powell (1969) has shown that the estimates do not depend on which equation is deleted.

29. See Smiley (1970), Carter (1971) and Simeon (1972) for a history of federal-provincial economic arrangements during this period. The earliest available observations, those for 1950, are unreliable, and since (8) includes one lag we begin with 1952. Public finance data subsequent to the $1969 / 70$ fiscal year is not compatible with prior years (it is then measured on a 'gross' rather than the older 'net' basis) and does not provide sufficient degrees of freedom by itself to overcome multicollinearity problems. 
32.

30. The test uses an F statistic (see for example Maddals, p. 324) which allows the intercept term to vary across cross-section units. The test is rough because there are endogenous variables on the righthand side of (8).

31. Heteroscedasticity across cross-section units for given t was eliminated in the usual manner, by estimating (8) and then using the computed standard errors to transform dependent and independent variables, including the constant term. Al $l$ estimates reported here and in Table 2 are based on the transformed data". Also, equation (8) was estimated with, and without, Quebec in the sample for each of the chosen subperiods. This is because Quebec was the only province to 'opt-out' of some of the shared-cost grant programs. Finally, note that the start and end of subperiods corresponds either with the main sample period, or with the fiscal year in which federal-provincial arrangements were renegotiated.

32. The estimates are rough because a change in the system of grants as a whole may not be given by the estimates i n Table 2, which strictly speaking reflect behaviour for a given structure of the federation. The coefficients of (8) may shift if the structure of the federation does.

33. I say, at least, because the calculations are based on impact multipliers. 


\section{Data Appendix}

$G=G^{C}+G^{U}$ : Unpublished Department of Finanœ sumaries of federal payments to the provinoes.

$G^{C}=$ conditional grants, including value of opting-out tax and cash abatements to Quebec; by fiscal year; millions.

$\mathrm{G}^{\mathrm{U}}=$ unoonditional grants, excluding revenue collected by the federal government on behalf of the provinces; by fiscal year; millions.

$\mathrm{N}$ = population as of Jume $I$ of the calendar year in which a fiscal year ends; thousands: Statistics Canada, National Income and Expenditure Accounts, Volume 1, \#13-531.

$\mathrm{P}=\mathrm{GNE}$ price deflator, 1961 = 100; by calendar year: as for $\mathrm{N}$.

$Q$ = total 'net' provincial expenditure; by fiscal year; millions: Unpublished Statistics Canada historical revision. $\mathrm{x}^{1}=$ per capita personal income including federal transfers to persons, but excluding provincial transfers; by fiscal year; thousands: as for N, and Statistics Canada Provincial Econamic Accounts, \#13-213.

All nominal data were deflated by $\mathrm{P}$ where appropriate. $\mathrm{x}$ was converted to fiscal year basis by adding $\frac{1}{4}$ of a given calendar year to $3 / 4$ of the preceding year. The provincial transfer component of $\mathrm{x}^{1}$ for 1951-1961 was assumed to be the same as for 1962, which is the first year of the provincial econamic accounts.

The data are available on request. I am grateful to Mr. Tony Kerr and Mr. John Garmer of the Govemment of Canada for providing this data. However, neither is to be held responsible for the manner in which I have used the data. 


\section{REFERENCES}

D.A.I. Auld, "Provincial Govermments and Local Government Expenditure," Public Finance Quarterly, 4, 1976.

T.C. Bergstrom and R.P. Goodman, "Private Demands for Public Goods," American Econanic Review, 63, Jume 1973.

T.E. Borcherding and R.T. Deacon, "The Demand for Services of Non-Federal Governments," American Eoonomic Review, 62, 1972.

W. Brainard and J. Tobin, "Pitfalls in Financial Model Building," American Econamic Review, 58, 1968.

A. Breton, "A Theory of Governmental Grants," Canadian Journal of Eonomics, 2, May 1965.

A. Breton and A.D. Scott, The Economic Constitution of Federal States, University of Toronto Press, 1978.

S. Brittan, "The Politics of Excessive Expectations," (1974) in Brittan, The Economic Consequenoes of Democracy, Temple Smith, 1974.

, "Inflation and Derrocracy," in F. Hirsch and J. Goldthorpe (eds.) The Political Economy of Inflation, Harvard University Press, 1978.

E.K. Browning, "Why the Social Insurance Budget is "Too Large in a Democracy," Econonic Inquiry, 13, 1975.

J.M Buchanan, "Federalism and Fiscal Equity," American Economic Review, 1950.

G.E. Carter, Canadian Conditional Grants Since World War II, Toronto, Canadian Tax Foundation, 1971.

P.N. Courant, E.M. Gramlich and D.L. Rubinfeld, "The Stimulative Effects of Intergovernmental Grants: Or Why Money Sticks Where It Hits," Unpublished, University of Michigan, 1978.

T.J. Courchene and D.A. Beavis, "Federal-Provincial Tax Equalization: An Evaluation," Canadian Journal of Economics, 6, 1973.

M. Feldstein, "Wealth Neutrality and Local Choice in Public Education," American Economic Review, 65, 1975.

R. Filimon, "Aggregation and the Median Voter," unpublished, CarnegieMellon-University, 1979.

J.F. Graham, "Fiscal Adjustment in a Federal Country," in Intergovemmental Fiscal Relationships, Canadian Tax Papers, No. 40, 1979.

E.M. Gramlici, "State and Local Govermments and Their Budget Restraint," International Economic Review, 10, 1969.

"Intergovernmental Grants: A Review of the Empirical

Literature," in W. Oates (ed.), 1977. 
H.A.J. Green, Consumer Theory, Penguin, 1971.

H.M. Hardy, "Budgetary Responses of Individual Governmental Units to Federal Grants, Public Finance Quarterly, 4, 1976.

J. Henderson, "Local Govermment Expenditures: A Social Welfare Analysis," Review of Econamics and Statistics, 50, 1968.

D. R. Huggett, "Tax Base Haumonization," in Ontario Economic Council, 1977.

A. Isseman, "Interjurisdictional Spillovers, Political Fragmentation and the Ievel of Iocal Public Services," Urban Studies, 13, 1976.

P. Jay, Employment, Inflation and Politics, Wincott Lecture, London Institute of Economic Affairs, 1976.

G.E. Johnson and J.D. Tomola, "The Fiscal Substitution Effect of Altemative Approaches to Public Service Employment Policy," Journal of Human Resources, 12, 1977.

G.S. Maddala, Econometrics, MoGraw-Hill, 1977.

M. MoGuire, "An Econametric Model of Federal Grants and Iocal Fiscal Response," in W. Oates (ed.), Financing the New Federalism, Johns Hopkins University Press, 1975.

, "A Method for Estimating the Effect of a Subsidy on the Receiver's Resource Constraint: With An Application to U.S. Iocal Governments, 1964-1971," University of Maryland, unpublished, 1977.

R.A. Musgrave, "Approaches to Fiscal Theory of Political Federalism," in J. Buchanan (ed.), Public Finanoes; Needs Sources and Utilization, N.B.E.R., Princeton University Press, 1961.

W. Oates, The Political Econony of Fiscal Federalism, Lexington Books, D.C. Heath and Co., 1977.

Ontario Economic Council, Intergovernmentel Relations, Toronto, 1977.

R.A. Pollack and T.J. Wales, "Estimation of Complete Demand Systems from Household Budget Data," American Economic Review, 68, 1978.

A. Poweli, "Aitken Estimators as a Tool in Allocating Predtermined Aggregates," Journal of the American Statistical Association, 64, 1969.

W.W. Pormerehne, "Quantitative Aspects of Federalism: A Study of Six Countries," in Oates (ed.), 1977.

T. Romer and H. Rosenthal, "The Elusive Median Voter," Unpublished, Camegie-Mellon University, G.S.I.A., 1978.

, "Bureaucrats vs. Voters: on the Political Economy of Resource Allocation by Direct Democracy," forthoaming in the Quarterly Journal of Economics, 1979. 
G.J. Stigler, "The Econamics of Information," Joumal of Political Econoriy, $69,1961$.

, "Director's Law od Public Income Distribution," Journal of Law and Econamics, 1970.

A.D. Scott, "The Economic Goals of Federal Finance," Public Finanoe, 19, 1964.

R. Simeon, Federal-Provincial Diplomacy: The Making of Recent Policy in Canada, University of Toronto Press, 1972.

E.N. Slack, "Local Fiscal Response to Intergovernmental Transfers," Ontario Econamic Council, 1978.

D.V. Smiley, Constitutional Adaptation and Canadian Federalism Since 1945, Ottawa, Royal Comission on Bilingualism and Biculturalism, 1971.

S. Smith, "Pitfalls in Financial Model Building: A Clarification," American Economic Review, 65, 1975.

G.R. Sparks, "Econometric Estimation of Constrained Demand Functions for Assets," Ottawa, Bank of Canada, no date.

V.K. Srivastava and R. Tiwari, "Efficiency of Two-Stage and Three-Stage Least Squares Estimators," Econometrica, 42, 1978.

J.C. Strick, "Conditional Grants and Provincial Government Budgeting," Canadian Public Administration, 14, 1971.

G. Tullock, "The Charity of the Uncharitable," Westem Economic Journal, 1971.

D. Usher, "The Welfare Econonics of the Socialization of Cormodities," Joumal of Public Econamics, 8, 1977.

P.B. Waite (ed.), The Confederation Debates in the Province of Canada/ 1865, Moclelland and Stewart Lta., 1963.

E.G. West and S.I. Winer, "Optimal Fiscal Illusion and the Size of Goverment," forthcoming in Public Choice, 1980.

E.G. West, "Public Choice, Public Monopoly and Public Education," forthcoming Institute of Economic Affairs, London, 1980.

K. Wicksell, "A New Principle of Just Taxation," (1896), in R. Musgrave and A. Peacock (eds.), Classics in the Theory of Public Finanoe, MacMillan, 1958.

G. Young, "Federal-Provincial Grants and Equalization," in Ontario Economic Council, 1977. 